\title{
Britannian kansallisen talouden nousu ja murentuminen
}

Niklas Jensen-Eriksen

David Edgerton: The Rise and Fall of the British

Nation: A Twentieth-Century History. Paperback edition, Penguin Books 2019 (Hardback edition, Allen

Lane 2018).

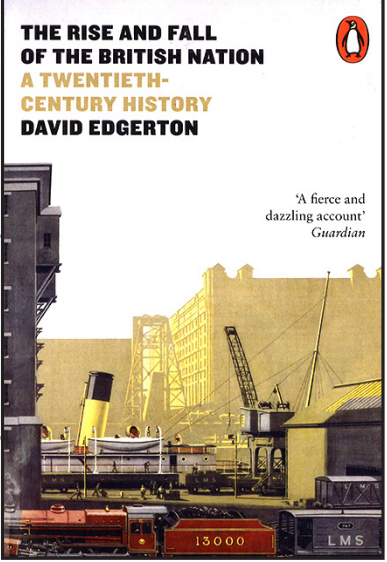

Ison-Britannian 1900-luvun historiasta on julkaistu lukuisia yleisteoksia, joista tuoreimpiin kuuluu David Edgertonin monipuolinen kirja "kansakunnan noususta ja laskusta" - tai peräti tuhosta. Talouden, yritysmaailman ja tekniikan historian tutkijan näkökulmasta kirja erottuu yleisteosten joukosta edukseen. Poliittisten taistelujen, sotien ja vaihtuvien hallitusten sijasta Edgerton keskittyy saarivaltion talouden ja yhteiskunnan muutoksiin, tekniikan kehitykseen ja niihin vaikuttaneisiin poliittisiin päätöksiin. Näitä asioita Edgerton on pohtinut jo vuosikymmeniä, ja hän onkin yksi Britannian tunnetuimpia tieteen ja teknologian historian tutkijoita.

Takkirauta ja voimalaitokset kiinnostavat Edgertonia enemmän kuin poliittisten taistelujen yksityiskohdat, kuten hän jo teoksensa johdannossa vihjaa. Tekniikan historiasta kiinnostuneelle lukijalle kirja antaakin paljon ajateltavaa, mutta Edgerton osoittaa vakuuttavasti näkökulmansa hedelmällisyyden myös suuremmalle yleisölle. Kirja vilisee kiinnostavia yksityiskohtia, tulkintoja ja väitteitä, jotka haastavat lukijan käsityksiä hyvinvointivaltion nousun ja valtion teollisuuspolitiikan kaltaisista asioista.

Kirjasta tulee vaikutelma, että tekijä on hakannut tietokoneensa näppäimistöä vimmalla ja voimalla. Edgerton julistaa haluavansa ravistella "kliseiden häkkiä" (cage of clichés), johon brittien historiallinen ja poliittinen mielikuvitus on hänen mukaansa vangittu. Sivuilta huokuu tekijän halu oikaista tutkijoiden, poliitikkojen ja suuren yleisön stereotyyppisiä, virheellisiä tai yksioikoisia näkemyksiä brittiyhteiskunnan kehityksestä. Yleensä hän ei tosin kerro kritisoimiensa henkilöiden tai julkaisujen nimiä. Näin lukija ei voi tarkistaa, kuka on sanonut mitä ja millä perusteilla.

Selvää silti on, että Edgerton ei taistele vain olkiukkoja vastaan. Hän osoittaa esimerkiksi, että hyvinvointivaltiota ei alettu rakentaa vasta vuonna 1945, kuten perinteisesti muistellaan, vaan konservatiivit asettelivat peruskiviä jo 1920-luvulla. Labour-pääministeri Clement Attleen (1945-1951) hyvinvointivaltio ei kansainvälisesti vertailleen ollut erityisen antelias tai laaja. Lisäksi "warfare state" jatkoi elämäänsä "welfare staten" rinnalla. Brittihallitukset kaatoivat rahaa hyvinvoinnin lisäksi - tai jopa enemmän - asevarusteluun. Britannia rakensi esimerkiksi itsenäiseksi mainostetun ydinpelotteen, mutta oli todellisuudessa riippuvainen Yhdysvalloista tällä ja monella muulla saralla.

Kirjan nimi on herättänyt hämmennystä, ja Edgerton joutuukin selittämään sitä pehmeäkantiseen versioon (johon tämä arvostelu perustuu) kirjoittamassaan uudessa esipuheessa. Nousulla ja laskulla hän ei tarkoita Britannian valta-aseman kehitystä suhteessa mui- 
hin maihin. Kyseessä ei siis ole Paul Kennedyn The Rise and Fall of the Great Powers -klassikkokirjan kaltainen tutkimus, joka kuvaisi ja selittäisi miten ja miksi suurvallat nousevat mahtiasemaan ja tippuvat sieltä tavallisten maiden joukkoon. Britannian suhteellisen aseman murentuminen ei Edgertonin näkökulmasta ole ilmeisesti edes erityisen kiinnostava kysymys. Hän pitää selvänä, että saarivaltion mahtiasema alkoi heikentyä, kun suuremmilla resursseilla varustetut maat nousivat toisen maailmansodan raunioista.

Puhuessaan Britannian kansakunnan noususta ja laskusta Edgerton tarkoittaa, että ennen toista maailmansotaa maa oli imperiumista ja maailmantaloudesta riippuvainen alue, jolle puhtaasti kansallinen näkökulma oli vieras. 1900-luvun alkaessa Britannia oli maailman suurin tuonti- ja vientimaa. Sen eliitti investoi rahojaan maailmalle, ja perinteinen englantilainen aamiainen koostui pääosin ulkomailta tuoduista ruoka-aineista. Vuosisadan keskivaiheilla Britanniaan luotiin kuitenkin valtiovallan johdolla ja protektionististen muurien suojassa leimallisesti kansallinen talous, joka tuotti valtaosan saarivaltion tarvitsemista elintarvikkeista ja teollisuustuotteista. Teollisuus, tiede ja infrastruktuuri laajenivat, ja samalla maa "vapautui" imperiumistaan. Yhdistynyt kuningaskunta ei ollut maa, joka menetti brittiläisen imperiumin, vaan yksi niistä kansallisista yksiköistä, jotka syntyivät sen hajotessa.

Kansallinen näkökulma hallitsi toisen maailmansodan jälkeen brittipäättäjien ajattelua. Talousnationalismi (economic nationalism) on käsite, joka esiintyy jatkuvasti Edgertonin tekstissä. Jopa Aneurin Bevanin ja Tony Bennin kaltaiset Labour-puolueen vasemman laidan poliitikot näyttäytyvät Edgertonin kirjan sivuilla enemmänkin talousnationalisteina kuin sosialisteina. He halusivat kehittää Britanniaa nimenomaan kansallisena yksikkönä - valtion johdolla.

"Teknonationalismi" (techno-nationalism) oli voimissaan. Brittihallitukset käyttivät toisen maailmansodan jälkeisinä vuosikymmeninä valtavia summia erityisesti lentokoneiden, aseiden ja ydinreaktoreiden kehitystyöhön. Poliitikot kehuivat yliampuvasti brittien nerokkuutta, mutta pitemmällä tähtäimellä tulokset jäivät vähäisiksi. Kotimaiseen tutkimuspanostukseen perustuvat huipputeknologian tuotteet eivät pärjänneet kansainvälisessä kilpailussa, eivätkä siten tuottaneet toivottuja vientituloja.

Kansakunta alkoi murentua Margaret Thatcherin (1979-1990) aikana, kun taloutta vapautettiin ja raja-aidat murenivat. Lukijalle tulee selväksi, että Edgertonin mielestä tämä ei ole hyvä kehityslinja. Britanniasta tuli jälleen enemmänkin globaalin talousjärjestelmän osa kuin itsenäinen kansallinen talous. Ulkomaista syntyperää olevat miljardöörit kiilasivat Britannian rikkaimpien listojen kärkeen ja kansainväliset sijoittajat ostivat osakkeita ja yrityksiä. New Labour jatkoi Thatcherin viitoittamalla tiellä, eikä sitä voinut enää oikeastaan pitää vasemmistopuolueena. Jeremy Corbynin sosialistisempi Labour rajautuu kirjan tarkasteluajanjakson ulkopuolelle.

Edgertonin kirja päättyy vuosituhanteen vaihteen tienoille, mutta uusimman pehmeäkantisen version esipuheessa hän ei malta olla ottamatta kantaa myös Brexitiin. Se oli "lupaus ilman suunnitelmaa" (a promise without a plan). Radikaaleja uudistajia löytyy Britannian historiasta runsaasti, mutta aikaisemmilla ryhmillä on ollut suunnitelmia niiden toimeenpanosta. Brexitin kannattajilla sellaista ei ollut. Heidän ajattelunsa on omaperäinen sekoitus nationalismia, nostalgiaa ja uskoa vapaaseen kauppaan sekä epärealistisia käsityksiä maailmantalouden toiminnasta. Edgerton ei selvästikään ole vakuuttunut Brexitin kannattajien kyvystä rakentaa menestyvä kansallinen talous. 